\title{
Oorreding in evangelisasie
}

\author{
P J van der Merwe
}

Universiteit van Pretoria

\begin{abstract}
Persuasion in evangelism

Is persuasion as researched and applied in the different secular fields relevant to evangelism? To many evangelists this is hardly a question to consider, since they take a positive answer as self evident. It is a different matter however when faith in Jesus Christ is marketed as a means to heavenly retirement, or when the fears and $e$ motions of persons are manipulated in order to pressure-sell the gospel. This article looks at two examples of applied persuasion, i e in marketing, and in training and management. One of the aims of evangelism, conversion, is also considered. It is found that many of the principles and techniques of persuasion as formulated may indeed be used in influencing and persuading nonbelievers on condition that specific principles be honoured. The article aims at addressing four principles in this regard.
\end{abstract}

Dit lyk voor die hand liggend dat dit in evangelisasie gaan om die evangeliese beinvloeding en oorreding van mense wat van Jesus en sy kerk vervreemd geraak het. Beinvloeding en oorreding is egter terme wat vandag nie meer gebruik kan word sonder om die wye tegniese betekenis daarvan in verskeie dissiplines wat aan die Sielkunde verwant is, in aanmerking te neem nie. Daar bestaan rondom hierdie twee sake 'n rykdom van kundigheid wat dit moontlik maak om oorreding op 'n hoogs verfynde wyse te laat plaasvind.

Hierdie studie beoog om beinvloeding en oorreding in hulle tegniese verband na te gaan, 'n oorsig te maak van relevante kundigheid en die moontlike toepaslikheid daarvan in evangelisasie prinsipieel te verantwoord en kortliks te illustreer. 


\section{BEINVLOEDING EN OORREDING}

Indien daar iets soos Beinvloedingskunde sou wees, sou 'n mens dit êrens tussen Kommunikasiekunde en Gedragswetenskap moes gaan soek. Presies waar hierdie veld ingepas moet word, is nie duidelik nie, aangesien dit ' $n$ wye spektrum van verwante temas behels. Dit handel oor sake soos retoriek, oorreding, propaganda, indoktrinasie, gedragsmodifikasie, kondisionering, sensitiwiteitsopleiding, breinspoeling en manipulasie.

Selfs 'n oppervlakkige bibliografiese soektog aan die hand van die trefwoorde oorreding of persuasion bring aan die lig hoe uitgebreid daar oor hierdie saak geskryf is en hoe wyd die toepassingsmoontlikhede is.

Een van die duidelikste toepassings vind ons in bemarking. Dit verbaas ook nie dat ' $n$ beduidende deel van die materiaal uit dié oord afkomstig is nie. Die vernaamste oogmerk wat hier nagestreef word, is om die klant tot 'n koopbeslissing te bring en 'n afgeleide oogmerk is om hom/haar deel te mak van die firma se kliëntele.

Ons kyk na hierdie toepassing, juis omdat sommige evangelisasieprogramme neig om by bemarking (en spesifiek 'salesmanship') aansluiting te vind. Daar word ook die afgelope tyd al meer stemme plaaslik gehoor wat kerkuitbreiding met bemarking wil verbind.

'n Tweede toepassing lê op die terrein van vorming en/of bestuur. Hier is die vernaamste oogmerk van oorreding om 'n houdingsverandering by die betrokkene(s) te bewerk met die oog op inskakeling of beter inskakeling by die waarderaamwerk, kultuur en/of funksionering van die groep of instansie. Ons kyk ook na hierdie toepassing, omdat die relevansie daarvan vir evangelisasie voor die hand liggend is.

\subsection{Begripsomlyning}

Kamper (1983:v, 6) verkies om die term 'oorredende kommunikasie' te gebruik vir die toepassing wat hy in gedagte het, naamlik binne vormings- en bestuursverband. Daarmee toon hy aan dat sy soort oorreding 'n swaar persoonlike aksent dra. Oorredende kommunikasie word beskryf as 'n appèl op die intellek en gevoel van die gespreksgenoot met die doel om sy houding te verander en hom tot instemming te oorreed. Na suksesvolle oorredende kommunikasie aanvaar die ander persoon 'n nuwe instelling, gevolgtrekking en/of standpunt as sy eie. Kamper maak ook die volgende afleidings:

- Daar is geen dwang by oorredende kommunikasie nie.

- Dit is nie sinoniem met argumentering nie, omdat argumentering slegs die intellek betrek en die gevoelsaspek grootliks buite rekening laat. 
* In oorredende kommunikasie gaan dit grotendeels om die verandering van houding. 'n Veranderde houding impliseer veranderde menings en gedrag, en wel van meer blywende aard.

Beinvloeding en oorreding soos dit binne die verband van bemarking funksioneer, lề op die verlengstuk van reklame. Soos reeds gestel, is dit afgestem op die bemarking van 'n produk aan klante. In verkoopsoorreding word die klant gelei om eie behoeftes op te roep, agter te kom of te identifiseer. Die klant word oortuig om die bepaalde produk in antwoord daarop te aanvaar en 'n koopsbeslissing te neem.

Verkoopsoorreding het dus twee fokuspunte, te wete 'n saaklike en 'n persoonlike. Soos later aangedui sal word, word nie net die kogniwiteit en redelikheid van die klant aangespreek nie, maar ook sy affektiwiteit. Dit beteken dat daar tog ook sprake van 'n soort houdingsverandering is, alhoewel dit nie so op die voorgrond staan soos by die vorige toepassing nie.

'n Verdere verskil tussen die twee benaderings is dat eersgenoemde die lang termyn in die oog het, terwyl laasgenoemde hoofsaaklik die kort termyn in die oog het.

\subsection{Teenoor manipulasie}

Ten einde oorreding beter in perspektief te plaas, kyk ons kortliks ook na manipulerende beïnvloeding.

Manipulasie is die toepassing van kunsgrepe en onetiese beïnvloeding met die bedoeling om 'n persoon sonder sy medewete en moontlik teen sy wil te oorreed. Feite word maklik verdraai en alternatiewe word subtiel verbloem (Kamper 1983:10). Die respondent word na 'n positiewe gesindheid en motivering opgebou, al is dit met misleidende voorstellings en argumente. Daar word heeltyd gesinspeel op die beloning wat hy kan verwag as hy tot die einde saamspeel. Die teenprestasie wat van die respondent verwag word, word nie volledig uitgespel voordat die respondent homself verbind het nie. Manipulasie maak aanspraak op mense se selfsugtige behoeftes. Onkunde, onsekerhede, vrese, emosies en/of persoonlikheidsgebreke en die algemeen menslike neiging om verleentheid te vermy, word uitgebuit. Andersins word mense se ordentlikheid misbruik en hulle menswaardigheid vertrap. Die manipuleerder wil ten alle koste by resultate uitkom. Hy is hoofsaaklik in die kort termyn geïnteresseerd.

Uit literatuur wat geraadpleeg is, is dit duidelik dat beïnvloeding-en-oorreding as 'n tegniese term hanteer word wat manipulasie uitsluit. Shostrom maak ook 'n nuttige onderskeid tussen manipuleerders en aktualiseerders (aangehaal in McLaughlin 1979:17). Dit ly egter geen twyfel dat beïnvloeding en oorreding soos dit in die praktyk van bemarking toepassing vind, dikwels tot op die grens na manipulasie vorder en dit soms oorsteek nie. 


\section{EVANGELISASIE EN BEKERING}

Wanneer evangelisasie as 'n toepassingsveld vir beïnvloeding en oorreding ocrweeg word, word natuurlik nie daarmee te kenne gegee dat dit die enigste bedieningsterrein is waar dit moontlik van toepassing is nie. Veel hang af van die manier waarop evangelisasie verstaan word en die verhouding daarvan met sending enersyds en pastoraat, asook opsig en tug, andersyds. Aangesien 'n beredenering hiervan ons egter te ver van ons basiese tema sal wegvoer, word gewoon volstaan met die wyse waarop evangelisasie in die Nederduitsch Hervormde Kerk verstaan word. Evangelisasie is naamlik daardie deel van die apostolaat wat hom rig op kerkvervreemde volksgenote en assimileerbare persone met die oog daarop om hulle terug te lei na lidmaatskap van die kerk en 'n normale kerklike lewe, tot eer van die Heer van die kerk.

\subsection{Oogmerke van evangelisasie}

De Klerk (1979:56) beskryf die oogmerke van evangelisasie soos volg:

* Handhawing van God se eer.

* Bewaring en uitbreiding van die kerk as verbondsgemeenskap.

- Herstel en terugbring van die vervreemde of verlore verbondslidmaat.

Laasgenoemde kan ons insiens soos volg uitgespel word:

* Verkondiging van die evangelie aan die kerkvervreemde wat as gevolg van 'n siek of afwesige geloof so geword het of wat 'n generasie of meer van die kerk verwyder is, met die oog op sy bekering en herwinning.

** Herinvoeging in die gemeente.

Brillenburg Wurth (s a: 18) wys op die gevaar van kerklike propaganda en die najaag van getallewins in evangelisasie. Dit behoort nie te gaan om bevordering van die eie kerk of genootskap nie, maar om die heerlikheid van die Heer van die kerk.

Hy stel ook dat daar dikwels in reaksie op die piëtistiese oorbeklemtoning van 'siele wen' 'n Calvinistiese onderbeklemtoning van die Bybelse bekeringsoproep voorkom. Op 'n stadium het teoloë in Nederland, soos Van Ruler en Rasker, selfs die standpunt ingeneem dat dit nie om evangelisasie behoort te gaan nie, maar herkerstening, dit wil sê, nie die bekering van individuele kerkvervreemdes nie, maar die herkerstening van die ganse volkslewe.

En hoezeer iets als de herkerstening van ons volk ons ter harte dient te gaan, dat kan ook nooit betekenen, dat wij daarom nu maar over iets als de bekering ons minder zullen bekommeren. Stellig, wij zullen voor een individualistische versmalling van het begrip 'bekering' op onze hoede hebben te zijn. Bekering van de enkeling mag voor ons 
niet het laatste doel van ons werk zijn. Maar voor een herkerstening, waarbij de bekering van de enkeling van minder aanbelang wordt, daarvoor zijn wij toch wel heel huiverig....Daarom menen wij, dat gezerd mag worden, dat ook in het kader van de gereformeerde evangelisatie bezinning op de betekenis der bekering zeker niet misplaats is.

(Brillenburg Wurth s a:20, 21)

Hierop kan gesê word dat dit ewemin in die kader van Hervormde evangelisasie misplaas is. Beide evangelisasie en herkerstening het hulle plek binne die raamwerk van 'n groter apostolêre strategie.

\subsection{Bekering as Bybelse oproep}

Die begrip bekering as wegkeer van die verkeerde, ommekeer of terugkeer na God, kom reeds in die Ou Testament voor (bv Jer 3:14; Klaagl 5:21; Jes 44:22; 51:11; 55:7). Daar gaan dit om meer as ' $n$ verandering van idees. Wel om ' $n$ verandering van houding, wil en lewensrigting ten gunste van God en dit wat reg is. Bekering word gewoonlik vergesel of voorafgegaan van goddelike inisiatief, ingrype of bystand.

In die Nuwe Testament, veral in die sinoptiese evangelies, neem die bekeringsoproep 'n belangrike plek in. Verskeie woorde word gebruik om die saak mee uit te

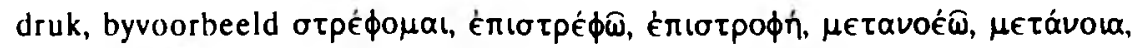

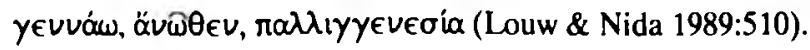

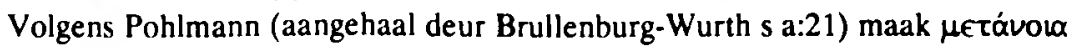
in die sinoptiese evangelies ' $n$ veel belangriker begrip uit as riorts. Dit word beide deur Johannes die Doper en Jesus verbind met die ingaan in die koninkryk (wat naby gekom het). Jesus stel dat Hy na die wêreld gekom het om sondaars tot bekering te roep (Matt 9:13; Mark 2:17; Luk 5:32).

Quanbeck (1962) keer die stelling om. Hy sê dat daar in die Johannes-evangelie en in die Pauliniese korpus 'n verskuiwing weg van die begrip bekering ten gunste van geloof te bespeur is. Hy verklaar dit egter as die resultaat van teologiese ontwikkeling en die besef dat die tradisionele begrippe wat met bekering vertaal word, nie reg kan laat geskied aan die nuwe, groter en voller werklikheid van 'n Christelike lewe in verhouding met die lewende Heer van die kerk nie. Geloof omvat die tradisionele begrippe en gee tegelyk uitdrukking aan die kontinuïteitsaspek. Bekering en wedergeboorte word dus nie deur die begrip geloof onnodig gemaak nie, maar in 'n breër raamwerk geplaas. 
Verkuyl (1978:17) skryf:

Bekering betekent inkeer, berouw, tot bezinning komen en afkeer van de zonde en toekeer tot God en de mensen. Op dat laatste valt de nadruk. Bekering gaat niet op in berouw, maar de nadruk valt op het positieve, het beginnen van een nieuw leven, je instellen iedere dag opnieuw op de nieuwe orde van zaken. Metanoia betekent bewust en telkens weer in wisselende situaties de consequenties trekken uit de aanvaarding van het goede nieuws, in het persoonlike leven en in de sameleving. Het is je voortdurend heroriënteren in je denken, in je emoties, in je gerichtheid, zodat daaruit een nieuwe levensstijl, een nieuwe manier van zijn, een nieuw gedrag ontstaat van dag tot dag.

Bekering is tegelyk menslike verantwoordelikheid (Hand 2:38, 3:19; 8:22; 17:30; 26:20) en goddelike gawe (Hand 3:26; 5:31; 11:18; Rom 2:4; 2 Kor 7:9; 2 Tim 2:25; Openb 2:21) vanweë die Heilige Gees (Hand 10:45; 11:15) (Quanbeck 1962). Die goddelike aspek word veral uitgedruk deur die metafoor wedergeboorte. Die mens word oorgemaak, 'n nuwe skepping. Dit moet in direkte verband met die nuwe bedeling verstaan word, dit wil sê die Koninkryk wat naby gekom het (Matt 19:28; Joh 3:5). Paulus voer die beeld van die gelowige as 'n nuwe skepsel tot 'n hoogtepunt (Rom 6:11; 2 Kor 5:17). Dit bly egter iets wat geglo moet word.

Die bekeringsoproep as 'n oproep na 'n nuwe lewenshouding, na 'n lewe wat Christus as Heer en Hoof erken, in Hom glo en God in Christus waarlik liefhet, bly dus onverminderd geld. Bekering is egter meer as 'n menslike beslissing of daad. Dit is ook goddelike genadedaad, trouens die genade van God maak dit moontlik (Joh 6:65). Die Reformatoriese beginsel is dat geloof deur Woord en Gees gewek word.

\subsection{Van bekeringsoproep na bekeringsdwang?}

So vreemd as wat dit ook mag klink, het dit in die geskiedenis van die kerk gebeur dat die bekeringsoproep in sommige gevalle bekeringsdwang geword het. Die gelykenis van Luk 14:15-24 oor die groot eetmaal is so geinterpreteer. Die woorde

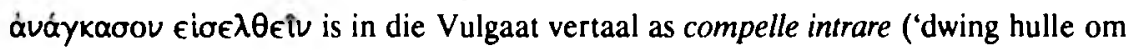
in te kom'). Augustinus het hierdie woorde as eksegetiese grond vir gedwonge herkatolisering aangebied (Kahl 1978). Karel die Grote het dieselfde Skrifberoep gebruik in sy gewelddadige 'sendingveldtogte', en so ook Olav Tryggvason in die jaar $1000 \mathrm{n} \mathrm{C}$ in sy gewelddadige kerstening van die Noorweërs (Bosch 1979:111). Dit het ook gedurende die Spaanse verowering van Sentraal- en Suid-Amerika in oormaat gefigureer. 
Bartolomeo de las Casas ' $n$ priester wat teen die geweldadige vernietiging van die Indiaanse kulture protesteer het, was een van die eerstes wat dit gewaag het om hierdie woorde anders te verstaan. Hy het vertaal: '...oorreed hulle om in te kom.' (Bosch 1979:118, 119). Die Afrikaanse vertaling van 1933 daarenteen het nog vertaal: '...dwing hulle om in te kom.' Die Nuwe Afrikaanse Vertaling vertaal egter: '...dring by hulle daarcp aan om in te kom.'

Dit is egter ' $n$ vraag of hierdie gelykenis en meer spesifiek die tweede en derde uitnodiging in 'n missionêre sin opgeneem behoort te word. Jeremias (1976:177) het betoog dat die basiese boodskap van die gelykenis is dat tye en geleenthede om deel aan God se eskatologiese heil te verkry, besig is om verby te gaan. Die bedoeling met dic uitnodigings was bloot om die feesplek te vul, omdat die gasheer nie van plan was om sy feesmaal enigsins skipbreuk te laat lei nie. Mense wat veronderstel is om vooraanstaand te wees, mag vind dat hulle hulle so besig hou met die dinge van hierdie wêreld dat hulle geleenthede laat verbygaan om deel te kry aan God se koninkryk. Ander wat deur hulle geminag is en volgens die Joodse tradisie nie veronderstel is om enige aansien te hê nie (Lev 21:18-20; 2 Sam 5:8), mag in hulle plek genooi word en die huis so vul.

Linnemann (1973:90) en Egelkraut stem daarmee saam. Egelkraut (1976:184 voetnoot) erken egter dat die gelykenis wel 'n missionêre toepassing gekry het:

It is almost opinio communis among NT scholars, E Linnemann is a rare exception, that the second invitation which reaches beyond the confines of the city, symbolizes the gentile mission. In Lk's text there is no indication of this. The second invitation is simply to underscore that in order to bring his plan to completion God would never resort to those who rejected his gracious invitation so thoughtlessly.

Hendrickx (1986:21) is ook van oordeel dat die gelykenis nie 'n eksplisiet missionêre betekenis dra nie, maar eerder in eskatologiese sin opgeneem behoort te word. Die metafoor van die eetmaal is ' $n$ standaard-metafoor vir eskatologiese heil. Dit is ook polemies: kritiek op die kontemporêre sosiale en godsdienstige bedeling word geimpliseer (vgl Luk 14:13).

Aan die ander kant is die vier groepe (armes, kreupeles, blindes en verlamdes) wat genooi is, nie sonder simboliese betekenis nie. Jesus heg self die betekenis van eskatologiese geregtigheid daaraan in Luk 14:13-14. Hendrickx verbind dit onder andere met Luk 4:17 en Jes 61:1, 2. Dit is interessant dat hierdie Skrifberoepe in die moderne Bybelse fundering van sending belangrik geag word. Verskeie uitleggers vind in die derde uitnodiging waar tot buite die stad gaste versamel is, 'n toespeling op die universele karakter van God se koninkryk en heil, en dat dit nie deur sosiale of godsdienstige grense ingeperk kan word nie. 
Hahn (1965:28) is meer uitdruklik oor die missionère verstaan van hierdie deel:

Es geht um die Teilnahme am endzeitlichen Heil...zu dem dann aber von den Straszen und Plätzen andere herbeigeholt werden. Zwar ist damit nicht ausdrücklich auf die Heiden angespielt, aber die herkömmlichen Grenzen werden in jedem Falle gesprengt und die spätere Gemeinde hat den Text mit gutem Grund auf die Mission bezogen.

Hy sê ook:

Noch an zwei weiteren Stellen des Reiseberichts, und zwar in Lk 13.28f...sowie in der lukanischen Fassung des Gleichnisses vom groszen Abendmahl Lk 14:16-24 mit dem zweimaligen Herbeiholen, wird auf das den Völkern zukommende Heil hingewiesen....

(Hahn 1965:113)

Die gelykenis is dus nie sonder betekenis vir die sending of evangelisasie nie en kan inderdaad in 'n missionêr-teologiese fundering aangewend word.

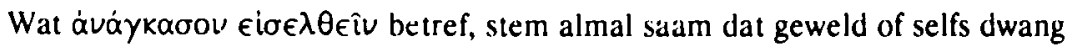
nie bedoel word nie. Hendrickx (1986:23) sê die volgende:

Needless to say, Luke is not thinking here of using force. But he knows that when one invites somebody one must show that one would really like him to accept the invitation. By insisting, one must make it possible for the other person to accept the invitation without offending the rules of courtesy.

Dit is duidelik dat Oosterse etiket hier ter sprake is. Toespelings op dieselfde saak vind ons ook in Gen 19:3; Luk 24:29 en Hand 16:15. Jeremias (1976:177) en Linnemann (1973:90) stem daarmee saam. Hier is hoogstens van 'n vriendelike aandrang sprake.

Dit val vreemd op dat in die geskiedenis van die kerk ooit by die konsep van bekeringsdwang uitgekom is, aangesien dit duidelik uit ander Skrifberoepe blyk dat die mens se beslissingsvryheid gehonoreer word. Die duidelikste in dié verband is stellig Joh 6:61-67 waar Jesus sy eie dissipels nooi om Hom te verlaat, indien hulle, soos die ander, nie langer kans sou sien om Hom te volg nie.

\subsection{Bekering, gelonf en oorreding}

Evangelisasie mik dus op die herstel van die siek geloof of die wek van geloof waar dit nie bestaan nie, en inskakeling by die gemeente en kerk. Die volgende beginsels kan gestel word: 
- Geloof is 'n lewende verhouding tussen mens en God wat beskryf kan word in terme van liefde, Vaderlike voorsienigheid en kinderlike vertroue en afhanklikheid. Dit is die gevolg van 'n ontmoeting tussen mens en God in Christus. Bekering kan dus as ontmoeting beskryf word met 'n duidelike heilsdimensie.

- Bekering kan ook as herkenning beskryf word - herkenning dat dinge sin uitmaak in terme van 'n evangeliese werklikheids-, lewens- en heilsvisie. Geloof is dus ook ' $n$ bepaalde manier om die werklikheid te sien en 'n bepaalde ingesteldheid daarteenoor. Die werklikheid waarom dit gaan, sluit nie alleen die natuurlike en mensgemaakte werklikheid in nie, maar ook die transendente werklikheid.

- Geloof word gedra en versterk deur die gemeenskap van gelowiges soos beliggaam in die kerk. Binne hierdie gemeenskap leef 'n kollektiewe geloof, asook die werklikheidskonsensus en kennis wat die geloof onderbou en wat gereeld binne die erediens deur die gepredikte Woord versterk word. Die erediens versterk ook die aanvanklike ontmoetingservaring (bv in die sakramente) en dra so by tot geloofsverdieping.

Bekering, wedergeboorte en geloof het nie net 'n menslike kant nie, maar ook 'n kant wat met die drie-enige God verband hou. Die Woord het 'n eie oortuigings$\mathrm{krag}$, omdat dit die goddelike waarheid is en die eintlike oorreding is geleë in die werking van die Heilige Gees. Daarsonder is bekering, wedergeboorte en geloof ondenkbaar. Die erkenning hiervan in die kerklike en teologiese tradisie waarvan die Nederduitsch Hervormde Kerk deel is, het gelei tot die afwysing van evangelisasie as bekeringskampanje, so asof dit binne menslike vermoë is om ander mense te bekeer. Die saad kan hoogstens gesaai word, maar dit berus steeds by God om die wasdom te gee.

Hierdie feit maak dit ook onmoontlik om bekering teoreties te rekonstrueer met die oog op die ontwikkeling van 'n oorredingsresep wat programmaties tot bekering lei. (Buitendien is dit, soos ons reeds gesien het, ' $n$ wanvoorstelling van oorreding). Aan die ander kant is die verkondiging van die Woord 'n verantwoordelikheid wat God aan mense in sy kerk gegee het. Woordverkondiging word van mens tot mens gekommunikeer. God gebruik die menslike kommunikasie om die wonder van geloof te laat gebeur, maar 'n swaar verantwoordelikheid rus steeds op die mens om die Woord reg en met sy volle rykdom te verkondig. Die volle kommunikasiespektrum kom so aan die orde, asook die manier waarop die evangelie voorgeleef word, nie alleen deur die verkondiger nie, maar ook die kerk.

Evangelisasie is 'n verantwoordelikheid wat in ewigheidslig gesien moet word. Die verkondiger moet hom bewus wees van die ewigheidsbetekenis van sy getuienis - dit mag die enigste kans wees wat die mens buite die kerk het om die heilswoord te verneem en met die goddelike liefde kennis te maak. Derhalwe behels die 
apostolère verkondiging 'n dringende uitnodiging. Die blye aandrang van Luk 14:23 is van toepassing. Die mense waarom dit gaan, moet kan agterkom dat die kerk wil hê dat hulle moet 'inkom'. 'n Neutrale of indifferente houding by die evangelis is net so min aanvaarbaar as 'n dominerende of manipulerende houding.

Hiervan kan ons aflei dat beînvloeding en oorreding, versover dit 'n verfyning van gewone kommunikasie is, wel sekere aanwendingsmoontlikhede in evangelisasie het, op voorwaarde dat die wilsvryheid van die respondent gehonoreer word. Wanneer beïnvloeding egter so geskied dat dit op manipulasie neerkom, word die vryheid wat Christus selfs sy dissipels nie ontneem het nie, tot niet gemaak. Dan word blye aandrang 'n verskoning vir liefdelose dwang.

\section{OORREDING OORWEEG}

In die volgende deel sal verskillende aspekte van oorreding en die toepassing daarvan in die twee genoemde oorredingsmodelle bekyk en die toepaslikheid daarvan in evangelisasie oorweeg word.

\subsection{Faktore by correding}

Die volgende sake kan as belangrike faktore by oorreding aangestip word:

\subsubsection{Persepsie}

Dit is subjektief-gekleurde waarneming waarin assosiasie, vorige ervaring en verwagting ' $n$ belangrike rol speel. Stereotipering en kontekstualisering is aan die orde van die dag.

Die werklikheidsvisie en -verstaan van die mens word saamgestel deur persepsies. Sommige beroepe of beroepstipes word deur negatiewe persepsies gekniehalter. Die verkoopsman is juis 'n goeie voorbeeld daarvan. In so 'n geval word daar met ' $n$ agterstand in die oorredingspoging begin. Aan die ander kant word daar in bemarking veel gemaak van produkpersepsie. Dit is ' $n$ gemeenplaas onder verkoopslui dat die persepsie van 'n produk verkoop word en nie soseer die produk self nie. Die evangelisasiewerker loop hom gewoonlik by buitekerklikes teen negatiewe persepsies van die Christendom, die kerk, gelowiges en geloof vas.

Die evangelisasiewerker het natuurlik ook 'n persepsie van die buitekerklike wat dikwels nie met die werklikheid ooreenstem nie. Hy moet dit as 'n uitdaging beskou om beide sy eie persepsies en die van die buitekerklike te deurbreek.

\subsubsection{Verbale kommunikasie}

Verbale kommunikasie wat op oorreding gemik is, kan as retoriek beskryf word. Retoriek kommunikeer houding. Godsdienstige taal is by uitstek retories van aard. Verbale kommunikasie dek 'n wyer spektrum as kognitiewe oorreding, aangesien 
woorde draers van emotiewe betekenis kan wees. Vanweë die semantiese oneksaktheid van taal kan hierdie faktor die potensiaal vir verbale misverstand baie verhoog. Dit gebeur veral in gespanne situasies waarin 'n vertrouensverhouding tussen die partye afwesig is of nog nie tot stand gekom het nie.

Die vestiging van ' $n$ taalafspraak is een van die voorwaardes vir die vestiging van 'n kommunikatiewe gemaklikheid in evangelisasiekontak. Die evangelisasiewerker moet hiervoor sensitief wees. Nida (1960:xvi) maak die stelling dat verskeie van die eietydse sendingmislukkings eintlik kommunikasiemislukkings was.

Argument- en bewysvoering maak 'n belangrike deel van oorreding uit, alhoewel baie afhang van die ander party se vermoë om die argumente te volg. Bewysvoering het byvoorbeeld 'n groter effek op die intelligente hoorder. Oor die algemeen lei dit tot 'n meer blywende houdingsverandering en bowendien stimuleer dit die kognitiewe prosesse van aanleer, nadenke en beredenering wat instrumenteel is in die skepping van 'n globale oorredingseffek (Kamper 1983:17). Bewysvoering veronderstel dat die oorreder ' $n$ uitgebreide kennis van die onderhawige saak het en in staat is om nuwe argumente in die situasie te bedink en te formuleer.

Teologiese argument- en bewysvoering verg natuurlik ook 'n minimum kennis en kundigheid, asook 'n vertroudheid met die Bybelse, kerklike en teologiese idioom. ' $n$ Verdere probleem is dat baie mense op 'n fundamentalistiese en biblisistiese wyse met die Bybel omgaan, of die persepsie het dat dit die korrekte manier is.

\subsubsection{Nie-verbale kommunikasie}

Kamper (1983:12) haal studies aan wat aan die lig gebring het dat nie-verbale kommunikasie in die normale gang van sake meer betroubaar geag word as verbale kommunikasie. Die rede daarvoor is dat die meeste mense lyftaal, gesigsuitdrukkings en stembuigings moeilik veins en dus 'n meer outentieke beeld daarmee kommunikeer. Hy verwys ook na 'n studie van Mehrabian (1971) waarin aangetrokkenheid ondersoek is en tot die volgende gevolgtrekking gekom is: 'Total liking $=7 \%$ verbal liking $+38 \%$ vocal liking $+55 \%$ facial liking' (Kamper 1983:11).

Hieruit volg dat oorreding kwalik moontlik is wanneer nie-verbale kommunikasie verbale kommunikasie weerspreek, maar dat die oorredingspoging versterk word wanneer die twee harmonieer.

\subsubsection{Houding}

As oorredende kommunikasie op die verandering van houding gemik is, maak houding 'n sleutelterm binne dié toepassing uit. Houding is 'n aangeleerde ingesteldheid en berus op ervaring. Allport (1935, aangehaal deur Kamper 1983:15) gee 
die volgende definisie: 'An attitude is a mental and neural state of readiness, organized through experience, exerting a directive or dynamic influence upon the individual's response to all objects and situations with which it is related.'

Houding is dus nie 'n vaste kenmerk nie, alhoewel dit deur karakter of persoonlikheidseienskappe beïnvloed word. Dit is iets dinamies wat voortdurend aanpas by nuwe lewensomstandighede. Maslow se bekende taksonomie van behoeftes kom gewoonlik ook hier ter sprake. Geloof oefen 'n bepalende invloed op houding uit.

Kamper (1983:15) onderskei na aanleiding van Katz (1960) die volgende aspekte en funksies van houding:

* 'n Ego-handhawence of -verdedigende houding, veral na vore gebring deur innerlike onsekerheid, nood of konflik.

* 'n Waardehouding, dit wil sê gebaseer en gerig op waardes, asook die handhawing. uitlewing of uitdra daarvan.

* 'n Kognitiewe houding, dit wil sê 'n houding wat as verwysingsraamwerk dien vir nuwe kennis.

* 'n Nuttighcidshouding, dit wil sê geïnteresseer in dit wat nuttig of potensieel nuttig is.

Verskillende toepassings van oorreding spreek verskillende aspekte van houding aan. Die nuttigheidsaspek van houding is van sleutelbetekenis in die verkoopsgesprek. Die waarde-aspek van houding speel weer in die geval van evangelisasie ' $n$ belangrike rol. 'n Sterk ego-verdedigende houding werk negatief by oorreding ongeag die party by wie teenwoordig is.

\subsubsection{Emosie}

Een van die duidelikste eienskappe van menswees is emosionaliteit. Selfs eksterne inligting word daardeur gekleur. Emosionaliteit word deur temperament bepaal.

Die emosionele appèl dra oor die algemeen groot gewig en word dikwels misbruik om impulsiewe besluite te bevorder. Kamper (1983:16) verwys na die moontlikhede wat die emosionele appèl vir manipulasie inhou en maak gewag van vreesinboeseming, openlik of subtiel, as 'n effektiewe manier van oorreding. Dit is 'n bekende verskynsel in evangelisasie dat emosies en vrese gebruik word om mense tot geloofsbeslissings te manipuleer. Dit hou egter ook risikos in deurdat die soort appèl byvoorbeeld te deursigtig word en deur die mat val, of afslyt en daartoe lei dat die 'geloof' wat in stand gehou is, verdwyn.

Aan die ander kant het geloof en die geloofshouding baie met emosie te doen, omdat dit handel oor sake wat vir die gelowige allerbelangrik is. Daarom kan die evangelisasiewerker nie oor geloofsake op 'n emosielose wyse spreek nie. 


\subsubsection{Interpersoonlike faktore}

Kamper (1983:13) stel dat oorreding berus op die totstandkoming van 'n vertrouensverhouding tussen die partye. Davis \& Silk (1971) het 'n studie van verkoopstegniek gemaak en tot die volgende gevolgtrekkings gekom.

- Persoonlike verkoopsukses wentel rondom die verskynsel van geslaagde verkoper-koper-interaksie.

- Dit hang weer af van die mate waarin verkoper en koper mekaar as gelykes ervaar. Dit sluit ouderdom en ervaring in. Interessant genoeg voel kopers dikwels bedreig wanneer die verkoper homself 'te veel van 'n spesialis' openbaar.

Dit is bevind dat 'n klant vertroue in 'n verkoper ontwikkel wanneer so 'n verkoper naby uitkom aan wat die klant as 'n ideale verkoopsman beskou. Wanneer dit gebeur, sal die klant in die toekoms so 'n verkoopsman telkens bo ander verkoopsmanne verkies.

Die beginsel wat hier ons aandag trek, is die van interpersoonlike gelykwaardigheid. Oorreding word in die hand gewerk wanneer die responderende party hom- of haarself nie te veel die ongelyke van die oorredende party ervaar nie. Kamper (1983:27) verwys ook na verskil in status tussen oorreder en respondent as een van die moontlike stremmende faktore. Wanneer daar ' $n$ te groot verskil bestaan, neig die ego-handhawende aspek van houding om te versterk. In die geval van 'n baasklaas-verhouding neig laasgenoemde weer om die rol van 'n inskiklike respondent te speel en vind geen werklike oorreding plaas nie. Die toepaslikheid hiervan vir evangelisasiekontak verdien stellig oorweging.

\subsubsection{Persoonlikheidsfaktore}

Roloff het eksperimente en publikasies nagegaan wat die persoonlike element in beïnvloeding bestudeer het (Roloff 1980).

Hy verwys na identiteitsbewussyn as faktor by beïnvloedbaarheid. (Hy gebruik in der waarheid die term 'self-consciousness'. By nadere oorweging blyk dit egter die ekwivalent van identiteitsbewussyn te wees.) Dit word bepaal deur twee faktore, te wete selfbewussyn en selfmonitering.

Wat eersgenoemde betref, is daar eerstens diegene met 'n private selfbewussyn. Hulle beoordeel hulleself aan die hand van eie, innerlike norme en waardes. Verder kry ons diegene met 'n publieke selfbewussyn. Hulle beoordeel hulleself aan die hand van andere se opinie van hulle. Laastens is daar diegene met 'n sosiaalonsekere selfbewusssyn. Hulle voel baie ongemaklik en selfs bedreigd in die teenwoordigheid van andere. Hoewel hierdie sake as breë kategorieë gebruik kan word, is dit belangrik om daarop te let dat die kategorieë mekaar nie uitsluit nie. In studies is bevind dat diegene met 'n private selfbewussyn duideliker emosies 
vertoon, 'n meer realistiese selfkennis openbaar en, soos te verwag, hulle minder aan ander se opinies steur. Daarenteen het beide diegene met 'n publieke selfbewussyn en 'n sosiaal-onsekere selfbewussyn makliker beinvloedbaar geblyk, behalwe dat hulle miskien moeiliker tot 'n besluit gekom het.

Selfmonitering het te doen met die vermoë om situasies reg te lees en sosiaal gepas daarin op te tree. Dit is ook 'n vermoë om emosies te kommunikeer en gepaste emosies in situasies te vertoon (al woed daar ander gevoelens in die eie gemoed). Diegene wat 'n hoë telling in selfmonitering gekry het, het hulle oor die algemeen met groter selfversekerdheid in sosiale situasies gedra as diegene met 'n lae telling. Laasgenoemde groep het meer sosiale onsekerheid vertoon as eersgenoemde. Eersgenoemde was meer ekstrovert en laasgenoemde meer introvert. Interessant genoeg, wanneer 'n hoë-selfmonitor en 'n lae-selfmonitor in 'n gespreksituasie beland, is dit eersgenoemde wat gouer ongemaklik en selfbewus raak. Die rede daarvoor is dat die hoë-selfmonitor, vanweë sy hoër sosiale IK ook meer ingestel is op sosiale stimuli, terwyl die lae-selfmonitor vanweë sy relatief swakkere sosiale IK minder vir sosiale stimuli omgee.

Die hoë-selfmonitor is meer geneig om teen eie houding en gevoelens in op te tree as die sosiale opset daarna vra. So 'n persoon sal meer vatbaar wees vir verkopersbeïnvloeding as die lae-selfmonitor.

'n Leierstipe is gewoonlik iemand met 'n private selfbewussyn en 'n hoë selfmoniterende vermoë. Die tipiese akademikus sal iemand wees met 'n private selfbewussyn en 'n lae selfmoniterende vermoë. Die verkoopsman kan iemand met 'n publieke selfbewussyn wees, maar moet verkieslik 'n hoë-selfmonitor wees. Die evangelis is dus verkieslik iemand met 'n private selfbewussyn en 'n hoë-selfmoniterende vermoë. Indien hy 'n lae-selfmonitor is, sal hy 'n ander strategie nodig hê ten einde beïnvloeding te laat slaag.

Kamper (1983:13w) verwys na studies waarin bevind is dat mense wat 'n negatiewe selfbeeld, depressie, 'n swak sosiale aanpassing of ' $n$ inhibisie van aggressie openbaar makliker oorreedbaar is, terwyl mense met neurotiese angsgevoelens en voortdurende obsessies moeilik oorreedbaar is. Die oorreder moet empatie en medemenslikheid kan openbaar, terwyl kenmerke soos outokrasie, beterweterigheid, ongeduld en bombasme oorreding strem.

Orpen noem die volgende persoonlikheidskenmerke van 'n suksesvolle verkoopsman (Orpen 1979): Dit is iemand met

- 'n sosiale aanleg.

* eerlikheid,

- verantwoordelikheidsbesef,

- selfvertroue en

- aanhou- en deursettingsvermoë. 
Die vraag bied homself aan of sekere persoonlikheidstipes ongeskik is vir evangelisasieoorreding. Hoewel 'n mens graag hierop ontkennend wil antwoord, is dit betekenisvol dat die Kuratorium van die Nederduitsch Hervormde Kerk reeds vir etlike jare sy kandidate vir die teologiese opleiding aan 'n multidissiplinêre keuringsprosedure onderwerp. Verskeie kandidate is al op grond van hulle persoonlikheidstipe aangeraai om nie die teologiese studie aan te pak nie.

Roloff verbind selfbewussyn ook met kommunikatiewe sensitiwiteit. Verlaagde selfbewussyn verlaag sensitiwiteit en daarmee die moontlikheid van oorreding. Oorbekendheid lei dikwels tot geykte gedrag en daarom tot verlaagde selfbewussyn. 'n Verkoopsman wat sy aanbieding al 'n dosyn keer of meer gedoen het, verkeer in 'n staat van verlaagde selfbewussyn. Die verkoper met 'n verlaagde selfbewussyn word deur die koper as saaklik en onpersoonlik ervaar. Dit is bevind dat die oorgrote persentasie van verkopers verkoopsituasies ingaan met 'n verkoopsresep. Soos ons later sal sien, hou dit voordele in. Dit kan egter ook teenproduktief werk. Dieselfde geld vir evangelisasiegespreksleiers.

Omdat die verbruiker vandag aan 'n onophoudelike stroom van advertensies en verkoopsbeinvloeding onderwerp word, is hy al tot 'n groot hoogte daarteen geïmmuniseer. Die tipiese koper verkeer dus in 'n toestand van lae selfbewussyn en verminderde sensitiwiteit. Suksesvolle verkoopsbeïnvloeding moet dus strategieë bedink om deur hierdie kors te breek. Dieselfde sou natuurlik ook gesê kan word van mense wat gereeld die objek van evangelisasieveldtogte van een of ander aard is.

Oor persoonlikheidsfaktore word hieronder by 3.2.1 verder gehandel wanneer die ideale oorreder bespreek word.

\subsubsection{Sosiale invloed en groepsdruk}

Groepsdruk is ook 'n belangrike faktor by oorreding bevind en berus op die menslike neiging om sosiaal in te skakel of te konformeer. Dit staan ook bekend as die 'band wagon'-effek (Kamper 1983:35). Davis \& Silk (1971) rapporteer eksperimente waarin gevind is dat ongeveer een-derde van naïewe kopers hulle deur die meerderheidsopinie laat beïnvloed, al is die opinie ook foutief. Hieruit het die tegniek van groepsverkoopsessies gespruit. Respondente wat skynbaar positief op ' $n$ aanvanklike aanbieding of voorligtingsessie reageer, word eerste aangespreek en van hulle af word deurgewerk na die meer hardne!:kige gevalle. Dit verklaar ook waarom groepwerk ' $n$ gewilde werkswyse in evangelisasie is.

'n Ander manier waarop die sosiale fakior betrek kan word, is deur gesaghebbende opinies aan te haal en na die korporatiewe beeld van die instansie wat verteenwoordig word, te verwys. Davis \& Silk (1970) het bevind dat 'n gunstige 'corporate image' verkope onteenseglik bevorder. Dit is duidelik dat hierdie beginsel hom ook tot misbruik en manipulasie leen. 


\subsubsection{Omgewingsfaktore en die kontekseffek}

Omgewingsfaktore wat oorreding beïnvloed, is byvoorbeeld fisiese omstandighede wat nie daarna is nie (bv ' $n$ beeldradio in dieselfde vertrek), ' $n$ telefoon wat kortkort lui en beantwoord moet word of selfs die respondent se gemoedstoestand. Elke oorredingsgesprek skep ook sy eie konteks namate dit vorder. Die ervare oorreder sal sensitief wees daarvoor en intuitief die nodige aanpassings maak. Hy sal ook weet wanneer omstandighede sinvolle kommunikasie met die oog op oorreding onmoontlik maak.

\subsubsection{Konflik, spanning en konfrontasie}

Dit is 'n natuurlike aspek van menslike kommunikasie. Kamper (1983:18) sê tereg dat konflik wat reg bestuur word, energie en kreatiwiteit kan ontsluit of mobiliseer wat andersins Jalk nie na vore sou kom nie. In sommige gevalle kan konfrontasie nie vermy word nie en kan dit trouens bevrydend wees. Dit beteken nie dat alle moeilike mense konfronterend benader moet word nie, aangesien daar uiteenlopende redes vir hulle gedrag mag wees (vgl in hierdie verband Ury 1991). Oorredende kommunikasie is by uitstek die instrument waarmee konflik bygelê kan word. Die gespreksgenoo: moet oorreed word om probleemgerig in plaas van persoongerig te dink. Die toepaslikheid hiervan vir evangelisasie spreek vanself.

\subsection{OORREDINGSTEGNIEKE EN -STRATEGIEë}

Deur faktore by oorreding te identifiseer, word die beginsels ook aangedui waarop die meeste oorredingstegnieke en -strategieë baseer word.

\subsubsection{Die ideale correder}

\subsubsection{Binne die konteks van bemarking:}

Die Russel-Buskirk-beginsels (aangehaal deur Orpen 1979) stel dat die goeie verkoopsman iemand is wat

- sistematies en konsekwent te werk gaan,

- tydens die verkoopsbesoek eerlik met die klant is en hom onder die indruk bring dat sy interesses vir hom net so belangrik is as sy eie belange,

- die klant se behoeftes ken of weet hoe om dit vas te stel,

* sy dienswilligheid/bereidwilligheid tot dienslewering altyd voorop laat staan, selfs in die geval van kopersweerstand,

- tydens die verkoopsbesoek nie met halfgebakte of onsekere aanbiedings vorendag kom nie; kompeterend is; eenvoudig en duidelik is, 
* die klant tydens die verkoopsbesoek toelaat om 'n aktiewe rol in die aanbieding te speel,

- nie grootdoenerig is oor eie vermoë nie, maar die klant dit eerder op indirekte wyse te laat agterkom,

* die klant tydens die verkoopsbesoek laat agterkom dat hy dit van hom verwag om te koop, sonder om dit direk ooit te sê,

- wat die klant se kritiek en besware nie beskou as fataal nie, maar dit as rigtingwysers tot die klant se persoonlikheid en behoefteprofiel hanteer,

* geldige kritiek tydens die verkoopsbesoek nie probeer wegpraat nie, maar er$k e n$, en dit tegelyk hanteer as ' $n$ vertrekpunt tot iets nuuts,

* moeilike gevalle nie maklik opgee nie,

* klagtes, versoeke en bestellings altyd opvolg en beloftes altyd nakom,

* belangrike inligting agterna altyd laat terugvloei na die verkoopsbestuur en

* altyd meer klante probeer bykry.

\subsubsection{Binne die konteks van vorming en bestuur}

Kamper (1983:25) stem saam dat baie afhang van die persoonlikheidstrekke van die oorreder. Hy beskryf die ideale oorreder soos volg (Kamper 1983:19vv):

* Wat persoonlikheidseienskappe betref:

* Die oorreder boesem vertroue in. Die oorreder moet eerstens persoonlik en saaklik geloofwaardig wees en sy motiewe moet suiwer en duidelik wees. Kamper noem die volgende komponente van geloofwaardigheid: deskundigheid, betroubaarheid, dinamiek, objektiwiteit en toegeneentheid. Dit is duidelik dat sommige hiervan alleen oor die medium of lang termyn van toepassing is en dus net vir sekere situasies kan geld. Baie hang ook af van die persoonlike styl van die oorreder, ook die moeilik omlynbare saak van charisma. Tweedens moet hy die respondent onder die indruk bring dat sy interesse waarlik ernstig geneem word. Hy moet die respondent met vrymoedigheid inspireer.

* Die oorreder het 'n positiewe selfbeeld. Hierdie saak gaan terug op wat ons reeds onder Persoonlikheidsfaktore bespreek het. Selfkennis en selfbegrip kan as 'n oorkoepelende voorwaarde vir geslaagde oorreding beskou word.

Kamper voeg hierby die volgende:

Persone met 'n positiewe selfbeeld praat maklik oor ander se prestasies, kan lof en kritiek goed verwerk, erken eie foute, is nie bevooroordeeld nie, benader uitdagings en probleme po- 
sitief en kan hulself in ander se skoene plaas. Eienskappe soos bogenoemde is in mindere of meerdere mate noodsaaklik om 'n openhartige kommunikatiewe situasie te stig.

(Kamper 1983:22)

* Die oorreder is taktvol. Dit het nie alleen met persoonlike styl te doen nie, maar ook met die wyse waarop omstandighede ingerig of benut word.

- Hiernaas beheer die oorreder ten minste ook die oorredingstegnieke wat hieronder by 3.2.3.2 bespreek word.

- Hy dra ook kennis van faktore wat oorreding kan blokkeer.

\subsubsection{Binne die konteks van evangelisasie}

Dit is nie moeilik om die relevansie van baie van die voorafgaande ideaalstellings vir die evangelisasiewerker of -gesprekvoerder in te sien nie. Die volgende hoedanighede en vermoëns kan ook opgenoem word:

- 'n Grondige kennis van die Bybel, wesenlike teologiese en kerklike sake, asook aktuele aangeleenthede. 'n Groot deel hiervan kan deur opleiding verkry word, maar voortdurende selfstudie is ook nodig

- Geloofwaardigheid, egtheid, eerlikheid. Die gepoleerde verkoopshouding is hier onvanpas. Slegs outentieke geloofstaal wat voortvloei uit die gelowige hart en gemoed is aanvaarbaar.

- Gesonde selfbeeld, sosiale en kommunikatiewe vermoë. Gesonde selfbeeld bestaan boweal uit selfrealisme en die wete dat die gelowige mens ten spyte van sy sondaarskap deur die dure bloed van Jesus Christus losgekoop is. In praktyk sal werkers gaandeweg egter rolle in die evangelisasiespektrum vind waar hulle meer tuis is.

Kamper (1983:25) sê hieroor verder:

Dit blyk dat die persoonlikheidstrekke van die kommunikator grootliks beslissend is in die keuse van oorredingstegnieke. (Hy) moet gevolglik deur deeglike selfondersoek, aangevul deur terugvoering van andere, sy ware self leer ken. Selfkennis en selfbegrip kan as die oorkoepelende voorwaarde vir geslaagde oorrende kommunikasie beskou word.

Die evangelisasiewerker moet hom egter nie te gou ongeskik vir die kontak- en gespreksaspek van evangelisasie verklaar nie, maar dit as 'n kosbare leerskool beskou. 
- Evangeliese antreklikheid, -gemotiveerdheid en -oorredingsvermoë. Evangelie beteken nie verniet 'blye boodskap' nie. Dit moet 'n lewende werklikheid wees in die lewe van die evangelisasiegesprekvoerder. Dit lei in die evangelisasiekontak tot die gesindheid van geesdriftige en blye aandrang.

* Respek vir gespreksgenoot en sy menswaardigheid. Dit maak manipulerende oorreding onmoontlik.

* Die vermoë om waarlik te luister en aanpasbaar te wees, maar om rigting te behou.

* Meelewing en beheer oor eie emosies. Die evangelisasiegesprekvoerder word aan heelwat spanning onderwerp. Hy moet kan meeleef sonder om ingetrek te raak Hy moet aanslae en vernedering kan verduur sonder om die basiese blydskap en geesdrif van die geloof te verloor.

- Realisme met betrekking tot die aard van bekering en geloof, en die feit dat nie alle mense vir die geloof voorbeskik is nie.

- 'n Voortdurende bewustheid van God as Derde Party tot die gesprek, van die selfoortuigende krag van die Woord en die feit dat die Heilige Gees die eintlike Verkondiger is. Hierdie wete en bewustheid maak dit moontlik om die risiko van evangeliese uitreik te aanvaar.

\subsubsection{Die betekenis van voorbereiding}

In oorreding word 'n hoë premie geplaas op voorafarbeid en voorbereiding. Dit sluit die volgende in:

\subsubsection{Saaklike kennis en - kundigheid}

Die verkoopsman moet 'n deeglike en gedetailleerde kennis van sy produk opdoen, omdat

- dit hom selfvertroue gee,

- hy vanself sal weet watter beslissende feite of argumente om te gebruik,

* hy kritiese vrae makliker sal kan hanteer en

* hy sy aanbieding sal kan modifieer om te pas by die behoeftes of profiel van die koper.

Dit spreek vanself dat die evangelisasiegesprekvoerder, soos reeds genoem, 'n grondige kennis van die Bybel, wesenlike teologiese en kerklike sake, asook aktuele aangeleenthede behoort te hè. Menige evangelisasiewerker wat onder die indruk was dat die evangelisasiegesprek bloot op die gevoelsvlak gevoer kan word, het al sy rieme styf geloop met iemand wat die nodige teenargumente geken het. Geloof is definitief nie net gevoel nie. 


\subsubsection{Klantprospektering en evangelisasiegerigte sensus}

Gewoonlik word daar eers 'n deeglike kopersopname van 'n gebied gedoen voordat dit aan bemarking onderwerp word. Die volgende moet vasgestel word: het die persoon die gewilligheid, die vermoë, die gesag om te koop en wanneer is hy/sy beskikbaar. Die individualiteit en eiendomlikheid van die klant is ook belangrik. Individuele behoeftes en verwagtinge moet, indien moontlik, vooraf vasgestel word. Vir hierdie doel kan verkennende gesprekke vooraf gevoer word. Dit is nie altyd maklik om toegang tot mense se huise te kry nie en daarom word dikwels van markopnames gebruik gemaak.

Die ekwivalent hiervan in evangelisasie is sensus. Die Raad vir Evangelisasie van die Nederduitsch Hervormde Kerk beveel verskeie maniere aan waarop dit gedoen kan word, afhangende van die omstandighede. Daar is sensus wat van huis tot huis gedoen kan word, telefoonsensus, selektiewe sensus aan die hand van inligting van lidmate verkry ensovoorts. Die doel van die sensus moet nie alleen wees om kerkvervreemde persone te identifiseer wat 'n inskiklikheid openbaar vir evangelisasiekontak nie, maar om in sulke gevalle ook inligting te verkry aan die hand waarvan voorbereiding vir'n gesprek getref kan word. Van die inligting kan gebruik word om 'n evangelisasiegesprekvoerder vir die gesprek te kies (vgl Interpersoonlike faktore hierbo).

Dit is waarskynlik sinvol om 'n verkennende gesprek te voer voordat 'n volwaardige en diepgaande gesprek gevoer word. So kan nog meer inligting verkry word wat sinvolle voorbereiding moontlik maak. Die voordeel van persoonlike sensus (van aangesig tot aangesig of per telefoon) is dat so 'n gesprek dadelik kan plaasvind indien die omstandighede dit toelaat of die respondent dit versoek. Daar moet gewaak word teen die gevaar dat sensus vinniger gedoen word as wat in gesprekke opgevolg kan word. Verwagtinge moet nie gewek waaraan nie voldoen kan word nie.

\subsubsection{Met die oog op die oorredingsgeleentheid}

Die aard van die geleentheid bepaal die struktuur daarvan. In die geval van 'n gesprek is die klassieke gesprekstruktuur van aanknoping, aktualisering, aanbieding, hoogtepunt en afronding van toepassing. Kamper (1983:24) gee twee ander strukture aan aan die hand waarvan die oorredende boodskap beplan kan word.

Afhangende van beskikbare inligting kan die gesprek of boodskap vooraf beplan word. Die ervare oorreder sal hom nie daardeur gebind ag nie, maar intuitief waak teen die uitrafeling van die gesprek. Cronje (1986) noem tereg dat enige vaardige evangelisasiegespreksleier rekening sal hou met die kontekseffek. Dit beteken bloot dat hy die situasie en konteks heeltyd in gedagte sal hou en nie blindelings met 'n gespreksagenda voortstu nie. 


\subsubsection{Beïnvloeding- en gesprekstegnieke}

\subsubsection{In die verkoopswêreld}

Die volgende beïnvloedingstegnieke word in die verkoopswêreld aangewend:

* Oorreding word gefasiliteer deur die sistematisering of strukturering van die boodskap. Dit lyk egter belangrik dat die struktuur wat gekies word vir die respondent taamlik deursigtig moet wees (Burgoon \& Bettinghaus 1980).

* Wanneer die respondent die boodskap in sy eie woorde oorsế of sistematiseer, verhoog dit die beïnvloedingskrag daarvan (Perloff 1980:89-90; soos hierbo aangedui, noem Orpen dit ook). Interessant genoeg voel sommige verkoopsmanne ongemaklik wanneer dit gebeur, waarskynlik omdat hulle vooraf-uitgewerkte aanbieding dalk deurmekaar kan loop. Hierdie beïnvloedingstegniek is nou verwant aan maieutiek of die sogenaamde vroedvroutegniek wat deur Sokrates ontwikkel is. Hiervolgens word die gespreksgenoot met slim vrae en opmerkings gelei om self by die gevolgtrekking uit te kom waarheen die gespreksleier mik. Met sekere voorbehoude kan dit ook in die evangelisasiegesprek gebruik word.

* Lei die respondent tot inkrementele toegewings en bou so op na die groot en eintlike beslissing. Die interessante is dat die aanvanklike toegewings net so wel deur 'n derde persoon teenwoordig gemaak kon gewees het. Alternatiewelik: Begin met 'n versoek/vraag wat so opgestel is dat die respondent dit moet verwerp. Volg dit op met'n meer redelike vraag/versoek. Die kanse is goed dat die respondent hierop positief sal antwoord. Die eerste vraag moet egter nie so verregaande wees dat die respondent hom vererg nie. Die twee tegnieke kan afwisselend gebruik word. Die toerustingsprogram Evangelism Explosion 3 maak van die tegniek van inkrementele toegewings gebruik, maar dit moet ongelukkig as manipulerend afgewys word (Cronje 1986).

* Sommige verkoopsmanne neem 'n derde persoon saam wat, hoewel passief, morele ondersteuning aan hulle kan verleen. Aangesien die klant in 'n numeries ongelyke posisie geplaas word, kan hy egter bedreig voel en van die staanspoor af negatief gestem wees. Alternatiewelik kan so 'n derde persoon as ' $t$ ware standpunt langs die respondent inneem en hom help om sy vrae of probleme te artikuleer, of die soort toegewings te maak waarna ons sopas verwys het. Dit implementeer die faktor van sosiale - of groepsdruk waarna vroeër verwys is.

Hierdie tegniek word in baie evangelisasieaksies toegepas, maar leen hom helaas ook tot manipulasie. 
* 'Distraction interfere with the generation of counterargumentation and will increase the persuasiveness of the communication' (Perloff 1980:76). Burgoon \& Bettinghaus (1980) noem enkele sulke aandagafleiers, byvoorbeeld geluide, flitsende ligte, uitdeel van leesstof, teenwoordigheid van 'n derde persoon, selfs die respondent se eie kritiese gedagtes. Hierdie tegniek is duidelik manipulerend.

- Daar is reeds verwys na die betekenis van 'n gunstige korporatiewe beeld. Sommige verkoopsmanne probeer klante teen teenaanbiedinge immuniseer deur te suggereer dat hulle teenstanders ' $n$ minder gunstige korporatiewe beeld het en dalk ook minder vertroubaar is. Waar evangelisasie niks anders as proselitering is nie of waar kerkgroei met selfbemarking bevorder word, is dit seker in orde om 'n derglike benadering te volg.

\subsubsection{In vorming en bestuur}

Kamper (1983:19) stip die volgende beginsels as belangrik by oorreding aan:

- Voorbereiding. Alhoewel resepmatige oorreding 'n onmoontlikheid is, is voorbereiding in 'n hoë mate moontlik. Veral die boodskap moet beplan en voorberei word.

* Goeie luistergewoontes. Dit klink na 'n vanselfsprekendheid, maar ongelukkig is baie mense swak luisteraars. Die ironie is dat mense selde deur 'n stortvloed van woorde oorreed word, maar deur iemand wat hulle ernstig neem.

- Gepaste taal- en stemgebruik. Taal is die verpakking waarin die boodskap gekommunikeer word. Dit is 'n kragtige medium wat selde behoorlik aangewend word.

- Positiewe versterking. Waar ons geneig is om te kritiseer, baat dit om in gedagte te hou dat waardering, vriendelikheid, erkenning, belangstelling en toegeneentheid meer konstruktief en effektief is.

\subsubsection{In evangelisasie}

Daar is 'n velerlei gespreksbeginsels en -tegnieke ter beskikking van die evangelisasiegespreksleier. Dit is egter belangrik dat die betekenis van geslaagde persoonsinteraksie en die stig van 'n vertrouensverhouding onthou word. Die betekenis daarvan kan kwalik oorskat word (vgl Interpersoonlike faktore). Die respondent moet ook as mens waarlik ernstig geneem word.

As deel hiervan moet die gespreksleier probeer om 'n empatiese houding te handhaaf. Dit beteken dat hy hom moet probeer inleef in die posisie van die gespreksgenoot en hom nie bloot as gehoor of klankbord gebruik nie. Verwant hieraan is die belangrike beginsel van egtheid en geloofwaardigheid waarna ons reeds verwys het. 
Die beginsel van gelykheid speel 'n belangrike rol by persoonsinteraksie. Aan sekere aspekte daarvan kan die gesprekvoerder nie veel doen as hy eers in die gespreksituasie is nie, byvoorbeeld geslag en ouderdom. Hy moet egter die versoeking weerstaan om die respondent te probeer beïndruk of homself bo die respondent te verhef. So iets gebeur makliker as wat 'n mens besef, omdat dit 'n natuurlike selfbeskermingsmeganisme is. Dit is egter ewemin aanvaarbaar om 'n kruiperige houding in te neem.

Selfonthulling is 'n nuttige gesprekstegniek. Die gespreksgenoot kan aangemoedig word om meer van homself en sy eie werklikheidsbelewenis mee te deel deurdat die gespreksleier iets van homself of sy eie geloofsverstaan vertel. Deur selfonthulling kan die respondent ook agterkom dat die gespreksleier nie verskuilde oogmerke het nie.

Die waarde van 'n voorafuitgewerkte skema is reeds genoem.

Die tegniek van terugkaatsing is ook genoem. Dit behels dat die gespreksleier eintlik niks nuuts toevoeg aan wat die ander persoon sê nie, maar dit bloot in ander woorde aan hom terugsê en hom so lei tot selfonthulling, -ontdekking en -insig. Die waarde van die tegniek staan bo twyfel, veral as 'n manier van luister, maar dit hou ook die gevaar in dat 'n persoon niks byleer nie. Die tegniek kan dus nie alleenstaande aangewend word nie.

Indien die respondent neig om 'n aktiewe aandeel te neem, laat hom dit doen. Daar moet gewaak word teen 'n gesprekstyl wat in die geheel nie-direktief of direktief is. Dit spreek vanself dat daar gestreef moet word na 'n balans tussen die twee, maar ook dat die aard van die balans bepaal sal word deur elke situasie.

Die gesprek moet so gevoer word dat nòg gespreksvoerder nòg die ander party in 'n toestand van lae selfbewussyn verval en kommunikatiewe sensitiwiteit afneem (vgl Persoonlikheidsfaktore).

Konfrontasie kan soms nie vermy word nie. Dit kan nodig wees word om die bravade of valsheid van die gespreksgenoot te ontmasker.

In die laaste plek moet onthou word dat God ook 'n party tot die gesprek is. Hierdie bewussyn kan lewend gehou word deur gebed 'n element van die evangelisasiegesprek te maak.

\section{- 4. DIE EVANGELISASIEGESPREK}

Evangelisasie behels ' $n$ wye spektrum van dissiplines en handelinge. Die gesprek word bloot bespreek om die toepassing van oorredingsbeginsels te illustreer.

Die struktuur wat gevolg word, hang grootliks van die omstandighede en die situasie af. Kamper (1983:25) noem tereg dat daar geen standaardplan bestaan vir die oorredende gesprek nie, ofskoon daar ' $n$ aantal kommunikasiemodelle bestaan 
met die oog op oorreding. In die volgende uiteensetting volg ons die klassieke gespreksmodel, sonder om dit as 'n Procrustesbed aan te bied waarop alle gesprekke moet inpas.

Teoreties gesproke is die verkoopsmodel van oorreding in die eerste fase van die evangelisasiekontak waarskynlik meer toepaslik as die vormingsmodel, omdat die aanvanklike oogmerke bloot is om die belangstelling van die kerkvervreemde persoon te wek en hom tot 'n evangelisasiegesprek te oorreed. In die loop van die gesprek (of gesprekreeks) sal daar geleidelik na die vormingsmodel oorbeweeg word waar die oogmerk is om 'n houdingsverandering te weeg te bring.

\subsection{Die aanvang}

Die begin van die gesprek is van strategiese betekenis. Indien die gespreksgenote nog nie vantevore ontmoet het nie, staan hulle vreemd teenoor mekaar en 'n ongemaklikheid heers. Daar bestaan tegnieke om die ys te breek, maar dit help baie as die gespreksleier van die begin af 'n gemaklike houding openbaar. Indien die kerkvervreemde tydens sensus aangetoon het dat hy so 'n besoek sou waardeer, is die gesprekvoerder as ' $t$ ware op uitnodiging daar. Dit vergemaklik die beginfase aanmerklik.

GETP stel voor dat die eerste fase daaraan gewy word om meer van die kerkvervreemde persoon (en sy gesin) uit te vind (indien sodanige inligting nog nie beskikbaar is nie) en van die geleentheid gebruik te maak om die eie kerkgenootskap bekend te stel. In die lig van die noodsaaklikheid dat 'n vertrouensverhouding gevestig word, is dit noodsaaklik dat die gespreksleier homself ook bekendstel. Dit is ook in ooreenstemming met die gesprekstegniek van selfonthulling. Die beginsel van persoonlike gelykheid moet egter in gedagte gehou word - die gespreksleier moet die ander persoon nie probeer beïndruk nie en homself ook nie te nederig gedra nie.

\subsection{Aktualisering en die wek van 'n behoeftebewussyn}

Dit is nodig dat die gesprek hierna aktualisering of gerigtheid opdoen, anders rafel dit uit in 'n gepraat. Gewoonlik word so iets gedoen deur middel van 'n vraag of twee te stel wat so geformuleer moet word dat die ander persoon se belangstelling gestimuleer word en ' $n$ vraag- of behoeftebewussyn by hom posvat.

$\mathrm{J}$ Cronje (1986) het in 'n studie van Evangelism Explosion 3 bevind dat EE3 op die selfsugtige begeerte van mense om 'in die hemel te kom' as 'n bemarkingsbehoefte fokus en dat geloof in Jesus Christus as ' $t$ ware as ' $n$ middel tot hierdie doel 'verkoop' word. Dit staan direk teenoor die Heidelbergse Kategismus wat die hoogste goed waarna 'n mens kan streef, beskryf as die liefde van God en om aan Hom te behoort. 
Die mening kan egter gewaag word dat EE3 in die regte koers beweeg, al is die spoor byster geraak. Die mees basiese vraag wat 'n mens stellig kan beantwoord, is: Wat is my ewigheidsbestemming? Watter sin hou my lewe in? GETP (1989) vra: 'Wat sou jy sê, is die belangrikste saak in 'n mens se lewe sodat jy met volkome gemoedsrus kan lewe en sterwe?' En nadat die persoon geantwoord het, die tweede vraag: 'Stem jy saam dat om in die regte verhouding met God te staan, die belangrikste saak in 'n mens se lewe is?' Hierop volg die derde vraag: 'Hoe sou jy sê, kan 'n mens in die regte verhouding met God gestel word?'

Waarskynlik kom GETP te gou by die punt uit waarheen enige evangelisasiegesprek op pad is. Die gespreksgenoot kan dalk so kerkvreemd wees dat GETP se eerste vraag hom nie eers aan God laat dink nie. GETP se tweede vraag wat die eerste vraag retories beantwoord, verteenwoordig 'n sprong wat die gespreksgenoot dalk nie sal kan volg nie. Miskien moet die volgende tipe vrae eers gestel word: 'Sal u saamstem dat die volgende vrae die belangrikste vrae is wat 'n məns homself kan afvra?

* Wat is die kosbaarste in die lewe?

* Waarheen is ek onderweg? Wat is my ewigheidsbestemming?

Die tweede vraag inhibeer uitspattige antwoorde op die eerste en daarom behoort hulle saam gevra te word.

In die bespreking wat hierop volg, kan gewys word op die vervlakking van die moderne lewe en die gebrek wat mense deesdae aan 'n diepere dimensie in hulle lewens ervaar. As die ewigheid eintlik so 'n belangrike rol in ons lewens speel, is dit vanselfsprekend dat die kosbaarste ding in ons lewens dit sal wees wat ewigheidsbetekenis dra. As hy saamstem, kan 1 Kor 13:1-13 voorgelees word, waaruit dit duidelik blyk dat net een lewenswaarde ewigheidsbetekenis het, naamlik die liefde.

Vervolgens kan die gesprek dan handel oor die vraag waarom die mens die liefde as hoogste deug herken, maar dit nie uitleef nie. Die antwoord hierop is tweërlei: Eerstens weet die mens nie wat liefde regtig is nie. Tweedens is die mens 'n gebroke wese wat nie in staat is om die liefde uit te leef nie. Hierdie gebrokenheid noem ons ook sondegeneigdheid. Die stelling kan gemaak word dat ons hier met die mees basiese en algemeen menslike probleem te doen het.

As die gesprek so ver gevorder het, is die tafel gedek vir die verkondiging van Jesus Christus as die Openbaring van die hoogste liefde, naamlik die liefde van God (met gebruikmaking van 1 Joh en ander paslike Skrifgedeeites), en as die Weg om die mens wat in ongehoorsaamheid en opstand van God vervreemd geraak en al dieper in die moeras van eiesinnigheid versink het, weer met Hom te versoen en so in sy liefde te herstel. Jesus Christus is nie alleen ons Redder uit sonde-ellende nie, maar $\mathrm{Hy}$ is ook die eintlike Mens: elke mens herken homself op een of ander manier in Jesus Christus. 
Uit die aktualisering moet 'n behoefte geïdentifiseer word. Die mens se probleme begin by eiesinnigheid en selfgesentreerdheid. So raak hy in der waarheid vervreemd van sy ewigheidsbestemming, van dit wat waarlik kosbaar is en van homself, want hy raak vervreemd van God. Hierop kan die tweede en derde vrae van GETP (effens aangepas) gevra word: 'Stem jy saam dat om in die regte verhouding met God te staan, dus eintlik die belangrikste saak in 'n mens se lewe is?'....'Hoe sou jy sê, kan 'n mens in die regte verhouding met God gestel word en sou jy ook in so 'n verhouding met God wou verkeer?' Die vraagstelling word dus van die algemene toegespits na die spesifiek persoonlike. Die gespreksgenoot word self aangespreek en op 'n subtiele wyse word hy onder die indruk gebring dat hierdie evangelisasiekontak uiteindelik keuses van hom gaan verg. Tegelyk is dit ' $n$ verdere diagnostiese vraag, want uit sy antwoord sal agtergekom word of hy iets van die Christelike geloof verstaan en wat hy daaronder verstaan.

\subsection{Aanbieding}

Hierdie fase van die gesprek kan as pre-kategetiese onderrig bestempel word. GETP se gespreksraamwerk kan goedskiks nagevolg word in die ontplooiing van die evangeliese boodskap en aanspraak. GETP stel voor dat Bybeltekste of kort Skriflesings gebruik word om strategiese vraagstellings te belig. In hierdie geval word 2 Kor 5:19 voorgelees. Enige ander paslike gedeelte kan ook gelees word, byvoorbeeld Joh 1:9-14. So leer die gespreksgenoot van vroegsaf omtrent die sleutelbetekenis van die Heilige Skrif en kom hy ook onder die indruk van die tydloosheid van hierdie waarhede.

Daar moet egter teen gewaak word om die gespreksgenoot met tekste te bestook. Tekste moet ook nie buite verband aangehaal word nie. Die volgende opmerkings moet nou gemaak word:

- Dit is onwaarskynlik dat 'n gesprek soos hierdie by een geleentheid afgehandel sal word, veral wanneer die feit in aanmerking geneem word dat elke mens 'n beperkte aandagspan het. Word 'n gesprek naderhand te lank, word die gespreksgenoot moeg en verloor hy konsentrasie. Derhalwe kan wat hier as 'n gesprek geskets word, in 'n aantal gespreksessies verdeel word. In so 'n geval is dit nodig dat elke sessie moet so ver moontlik ' $n$ afgeronde geheel uitmaak met gesprekstemas en gespreksdoelwitte.

- Dit help om die oorgange van sessie tot sessie te beplan. ' $n$ Sessie kan afgesluit word met 'n vraag wat by 'n volgende geleentheid opgevolg word. So sal die belangstellingslyn gehandhaaf word.

- Op 'n stadium kan 'n mens ook begin om 'huiswerk' te gee, byvoorbeeld dat sekere Skrifgedeeltes gelees en by die volgende geleentheid verduidelik moet word. 
* Die gesprek is nie 'n monoloog deur die gespreksleier nie. Die gespreksgenoot moet aangemoedig word om vrae te stel en selfs besware te opper, maar indien dit duidelik is dat hy aanhoudend die gang van die gesprek ontwrig en daarop uit is om die evangelisasiewerker te ontstig, kan dit as 'n sekere teken beskou word dat hy geen erns met die saak het nie.

- Probeer besware so hanteer dat nie te ver van die basiese plan afgedwaal word nie. GETP (1989) gee in Week 4: Lesing 4 'n aantal nuttige wenke hoe besware hanteer kan word. Moontlik het die gespreksgenoot oorspronkiik juis vanweë 'n diepliggende geloofs- of teologiese probleem vervreemd geraak. Andersins kan dit ingewikkelde persoonlike probleme wees wat hom laat ontspoor het. In die gesprek sal 'n mens weldra agterkom waarom dit gaan. Moenie huiwer om meer gespesialiseerde kundigheid te raadpleeg of so 'n persoon saam te nooi by 'n volgende sessie nie. Die gespreksgenoot moet egter nie die indruk kry dat teen hom saamgespan word nie en sy instemming moet vooraf daarvoor verkry word. Indien dit blyk dat 'n gesprek onmoontlik by die raamwerk kan bly wat deur GETP voorgestel word, moet dit sy eie vorm aanneem. Sommige gesprekke sal langer duur as ander. Dit kan selfs wees dat ' $n$ mens na so 'n lang en uitgerekte kontak tot die slotsom gaan kom dat die persoon kwalik oorreed sal word om nader na die kerk te beweeg. Toegespitste kontak kan dan gestaak word, maar miskien kan daar nog op 'n ander manier kontak met die persoon/gesin gehou word.

- Daar moet gewaak word teen die neiging om in 'n kognitiewe, lesingagtige styl te verval.

\subsection{Gespreksoogmerk}

Die bereiking van die gespreksoogmerk maak 'n hoogtepunt uit. Baie verkoopsmanne maak gebruik van 'n kwalifiserende vraag om te toets of die klant hiervoor gereed is. Engel (1975:70) stel dat sinvolle besluitneming net kan plaasvind wanneer kommunikator en respondent op vergelykbare vlakke van kennis en verstaan verkeer, versover dit die onderhawige saak aangaan.

Oor die verkoopsoomblik sê Orpen (1979): Die verkoopsman moet nie wegskram van die vraag of die klant gaan koop of nie, maar sistematies daarheen opbou. Aangesien dit 'n kritiese oomblik is, moet die volgende in aanmerking geneem word:

- Moenie 'n derde persoon toelaat om op hierdie oomblik tussenbeide te kom nie.

- Moenie gespanne raak by die stel van die groot vraag nie. Die klant kan bedreig raak. Tree kalm en normaal op, maar nie te ontspanne nie, want dit kan deur die klant as traak-my-nie-agtigheid geïnterpreteer word. 
- Kies die regte sielkundige oomblik vir die vraag, wanneer daar 'n hooggety van belangstelling te bespeur is.

* Hou 'n klompie argumente in reserwe indien die klant traag reageer.

- Onthou dat etlike onsuksesvolle pogings om 'n verkope te beklink, wel kan lei tot sukses.

- Moenie te opgedaan lyk by sukses of afgehaal by mislukking nie.

Die oogmerk van die evangelisasiegesprek (of -gesprekreeks) is om die kerkvervreemde te oorreed om 'n keuse ten gunste van Jesus se evangelie-aanbod te maak. Die gespreksleier is immers hiervoor gestuur.

Dit beteken dat van die ander party verwag word om:

- duidelik ja of nee te sê, en voortvloeiend uit 'n positiewe antwoord,

- nader na die kerk te beweeg.

Die vraag is nou hoe die betekenis van so 'n 'ja' opgeneem moet word.

GETP noem hierdie moment die geloofsbeslissing. Van die vernaamste kritiek wat in die verlede teen GETP uitgespreek is, is dat dit onrealisties is om na enkele gespreksessies so 'n beslissing te eis van iemand wat kort tevore dalk nog ' $n$ volslae heiden was. So ' $n$ kritiek is gekwalifiseerd geldig. ' $n$ 'Ja' in hierdie stadium moet nie noodwendig as 'n geloofsbeslissing beskou word nie (alhoewel dit natuurlik nie uitgesluit is nie). Dit kan gewoon beteken dat die persoon geinteresseerd is in wat hy gehoor het en bereid is om die pad verder te loop.

'n Persoon wat nie bereid is om homself binne so 'n kort tydsbestek bekeerd te verklaar nie, mag nogtans bereid wees om geleidelik al meer by die kerk in te skakel en die evangelisasiegerigte kategese te begin bywoon. Die evangelisasiestruktuur wat gevolg word, behoort hiervoor voorsiening te maak. In die loop van die kategese sal dit wel vir die persoon duidelik word of hy bereid is om in die gemeente belydenis van sy geloof af te lê of nie. Dit gebeur soms dat iemand bereid is om die evangelis se boodskap te aanvaar, maar nie bereid is om by sy kerkgenootskap in te skakel nie. Dit is ' $n$ moontlikheid waarmee enige evangelisasiepoging rekening moet hou.

\subsection{Afronding}

GETP noem hierdie fase 'opvolg'. Die bedoeling daarvan is om die gesprek of gesprekreeks op te knoop en af te rond, en om 'n oorgang te bied na wat GETP die 'amptelike nasorg' noem. Onder amptelike nasorg word verstaan dat die persoon onder die sorg van die ampte geplaas word met die oog op kategese, aanneming, doop/belydenis van geloof en inskakeling by die gemeente. GETP stel voor dat die volgende temas in hierdie fase behandel word: 
- Die aard en plek van die Bybel in die lewe van die gelowige.

- Die aard, plek en betekenis van gebed in die lewe van die gelowige.

- Erediens en sakramente en waarom die gelowige daaraan deel moet hê.

- Die gemeenskap van die gelowiges en die noodsaak en waarde van kerklike meelewing.

- Die gelowige as 'n getuie vir Christus.

Die laaste tema mag voor op die wa lyk, maar mak tog sin. Die persoon moet aangemoedig word om met ander mense oor geloofsake te praat, want so versterk hy die oorredingseffek wat die evangelisasiegesprek hopelik bereik het.

\subsection{Evangelisasiegerigte kategese}

Die neiging bestaan om volwasse kategese as gewone kategese te struktureer wat toevallig op volwassenes gerig is. Die vraag kan egter gevra word of volwasse kategese nie juis 'n evangelisasiegerigtheid moet hê nie, gesien die persone vir wie dit normaalweg aangebied word. Evangelisasiegerigte kategese is meer op oorreding ingestel. Dit veronderstel minder voorkennis as gewone kategese. Dit staan langer stil by die basiese sake en duur moontlik ook langer.

Die voordele van 'n skakeling tussen evangelisasiekontak en -gesprekke, enersyds, en evangelisasiegerigte kategese, andersyds, lyk duidelik. Behalwe dat die evangelisasieoorreding so versterk word, word die oorgang vanaf die evangelisasieomgewing na die pastorale omgewing, wat soms taamlik abrupt kan wees, versag. Wanneer iemand uiteindelik aangeneem en gedoop/belydenis van geloof afgelê het, behoort dit sterk oorweeg te word om so 'n persoon by die georganiseerde evangelisasie in te skakel. Die geloofsentoesiasme van nuwe gelowiges is kapitaal wat nie toegelaat moet word om te renteloos te bly nie.

\section{TEN SLOTTE}

Dit is natuurlik so dat evangeliese kommunikasie nie nodig het om in 'n gedragswetenskaplike of kommunikasiekundige dwangbuis ingedwing te word, asof dit die enigste resep vir suksesvolle kommunikasie of oorreding is nie. Die evangelie is suksesvol verkondig lank voordat sulke kundigheid beskikbaar was. Boonop gaan elke poging om die evangelie te betuig of te verkondig, uit van die veronderstelling, eerstens dat die Woord alreeds eie oortuigingskrag bevat omdat dit die waarheid is en, tweedens dat die eintlike oorreding geleë is in die werking van die Heilige Gees.

Ons lewe vandag egter in ' $n$ wêreld waarin die mens aan 'n voortdurende stroom van oorredingsboodskappe van een of ander aard en van wisselende sofistikasie onderworpe is. Die moderne mens het onbewustelik 'n fynproewer van oorredingsboodskappe geword, is in 'n hoë geïmmuniseer daarteen en staan ook redelik 
sinies teenoor oorredingspogings. Dit veroorsaak dat die oorredingstegnologie nog meer verfynd raak en dat die bose kringloop so versterk word. Evangelisasieoorreding word onwillekeurig aan hierdie maatstawwe gemeet deur die mense op wie dit gerig is.

Kerke is soms geneig om die moeilike veld van evangelisasie op 'n taamlike lukrake en ongestruktureerde wyse te betree, omdat aanvaar word dat geloof in elk geval van God is en dat die Heilige Gees die eintlike oorredingswerk doen. Dit is natuurlik waar, maar dikwels is dit ook 'n verskoning vir gebrekkige voorbereiding en taakgerigtheid.

\section{Literatuurverwysings}

Barnard, A C 1979. Die huidige evangelisasie-patroon, in De Klerk 1979:320-344.

Bosch, D J 1979. Heil vir die wêreld: Die Christelike sending in teologiese perspektief. Pretoria: NGK-Boekhandel.

Brillenburg Wurth, G s a. Die bekering als evangelisatie-probleem. Kampen: Kok.

Burgoon, M \& Bettinghaus, E P 1980. Persuasive message strategies, in Roloff \& Miller 1980:141-169.

Buttrick, G A (ed) 1962. The Interpreter's Dictionary of the Bible. New York: Abingdon Press.

Cronje, J 1986. Evaluering van EE3 en GETP (NHK) Evangelisasieaksies. Lesing voor Evangelisasiestudiegroep, Universiteit van Pretoria.

Cronje, J M \& Van Wyk, J A 1982. Van mens tot mens: Kerklike kommunikasie in teorie en praktyk. Pretoria: NGK Boekhandel.

Davis, H L \& Silk, A J 1971. Behavioral research on personal selling: A review of some recent studies of interaction and influence processes in sales situations. Cambridge, MA: Marketing Science Institute.

De KJerk, J J (red) 1979. Evangelistiek. Pretoria: NGK-Boekhandel.

Egelkraut, H L 1976. Jesus' mission to Jerusalem: A redaction critical study of the travel narrative in the Gospel of Luke, Lk 9:51-19:48. Frankfurt/aM: Peter Lang.

Engel, J F 1975. An end to guesswork in Christian book publishing, aangehaal in Cronje 1986.

Hahn, F 1965. Das Verständniss der Mission im Neuen Testament. 2.Aufl. Neukirchen: Neukirchener Verlag. (Wissenschaftliche Monographien zum Alten und Neuen Testament.)

Hendrickx, H 1986. The parables of Jesus. London: Geoffrey Chapman.

Jeremias, J 1976. The parables of Jesus, translation based on 6th impr. London: SCM. 
Kahl, H D 1979. Die ersten Jahrhundert des missionsgeschichtlichen Mittelalters: Bausteine für eine Phänomenologie bs ca 1050, in Schäferdiek 1978.

Kamper, G D 1983. Oorredende kommunikasie as bestuursinstrument van die skoolhoof. Ongepuhliseerde MA-skripsie, Randse Afrikaanse Universiteit.

Linnemann, E 1973. The parables of Jesus: Introduction and exposition. London: SPCK.

Louw, J P \& Nida, E 1989. Greek-English lexicon of the New Testament based on semantic domains, vol I. Cape Town: Bible Society of South Africa.

McLaughlin, R W 1979. The ethics of persuasive preaching. Grand Rapids: Baker Book House.

Nederduitsch Hervormde Kerk (GETP) 1989. Gemeentelike Evangelisasietoenusringpakket. Pretoria: Kital.

Nida, E 1960. Message and mission. 3rd reprint. Pasadena: W Carey Library.

Orpen, C 1979. Advertising; buying; selling: A behavioral science approach. Johannesburg: McGraw-Hill.

Perloff, R M \& Brock, T C 1980. '...And thinking makes it so': Cognitive responses to persuasion, in Roloff \& Miller 1980:67-100.

Quanbeck, W A 1962. Repentance, in Buttrick 1962.

Roloff, M E 1980. Selfuwareness and the persuasion process: Do we really know what we are doing?, in Roloff \& Miller 1980:29-66.

Roloff, M E \& Miller, G R (eds) 1980. Persuasion: New directions in theory and research. Beverly Hills: SAGE Publications.

Schäferdiek, K (Hrsg) 1978. Die Kirche des früheren Mittelalters. München: Kaiser. (Kirchengeschichte als Missionsgeschichte Band II.)

Shostrom, E L 1967. Man the manipulator: The inner journey form manipulation to actualization. Nashville: Abingdon.

Ury, W 1991. Gelting past no: Negotiating with difficult people. London: Century Business.

Van der Meiden, A 1973. Mensen winnen: De overdracht van de boodschap. Baarn: Uitgeverij Ten Have.

Verkuyl, J 1978. Inleiding in de Evangelistiek. Kampen: Kok. 